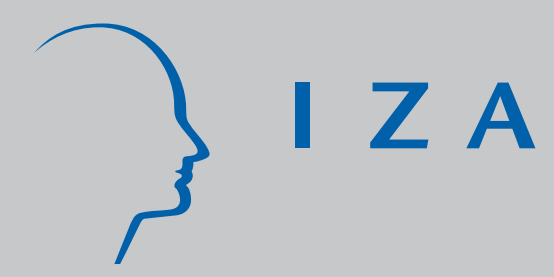

IZA DP No. 1438

The (Unexpected) Structure of "Rents" on the French and British Labour Markets

Andrew E. Clark

Claudia Senik

December 2004 


\title{
The (Unexpected) Structure of "Rents" on the French and British Labour Markets
}

\author{
Andrew E. Clark \\ CNRS, DELTA-Fédération Jourdan \\ and IZA Bonn \\ Claudia Senik \\ Université Paris IV \\ and DELTA-Fédération Jourdan
}

Discussion Paper No. 1438

December 2004

\author{
IZA \\ P.O. Box 7240 \\ 53072 Bonn \\ Germany \\ Phone: +49-228-3894-0 \\ Fax: +49-228-3894-180 \\ Email: iza@iza.org
}

\begin{abstract}
Any opinions expressed here are those of the author(s) and not those of the institute. Research disseminated by IZA may include views on policy, but the institute itself takes no institutional policy positions.

The Institute for the Study of Labor (IZA) in Bonn is a local and virtual international research center and a place of communication between science, politics and business. IZA is an independent nonprofit company supported by Deutsche Post World Net. The center is associated with the University of Bonn and offers a stimulating research environment through its research networks, research support, and visitors and doctoral programs. IZA engages in (i) original and internationally competitive research in all fields of labor economics, (ii) development of policy concepts, and (iii) dissemination of research results and concepts to the interested public.
\end{abstract}

IZA Discussion Papers often represent preliminary work and are circulated to encourage discussion. Citation of such a paper should account for its provisional character. A revised version may be available directly from the author. 


\section{ABSTRACT \\ The (Unexpected) Structure of "Rents" on the French and British Labour Markets*}

This paper considers the allocation of labour on the French and British markets, using objective wage and subjective satisfaction data. We show that, in some sectors, workers enjoy both higher wages and higher job satisfaction. We argue that this reflects labour market wage rents. Perhaps surprisingly, wage rents are typical of the British public sector and permanent contracts, but not of their French counterparts. In France, such rents are found in full-time, rather than part-time jobs. Hence, the data provide little support for the usual a priori that the French labour market is structured along insider-outsider model lines, whereby wage rents are captured by the insiders of the public sector to the detriment of the private sector. However, they do suggest that part-time employment is involuntary to a far greater extent in France than in Great Britain.

JEL Classification: $\quad$ C30, J28, J31, J41, M51

Keywords: job satisfaction, wages, self-employment, public sector, permanent, full-time, rents

Corresponding author:

Andrew Clark

DELTA-Fédération Jourdan

48 Boulevard Jourdan

75014 Paris

France

Email: Andrew.Clark@ens.fr

\footnotetext{
*We are grateful to Morris Altman, Allen McDowell and an anonymous referee for useful comments. The BHPS data were made available through the ESRC Data Archive. The data were originally collected by the ESRC Research Centre on Micro-social Change at the University of Essex. Neither the original collectors of the data nor the Archive bear any responsibility for the analyses or interpretations presented here. We thank INSEE for supplying us with the French component of the ECHP, and the ATIP programme of the CNRS for financial support.
} 


\section{Introduction}

An enormous amount of work in labour economics is devoted to the distribution of observable job characteristics, mostly wages and hours, across different labour market sectors. The motivation behind a great deal of this research has been the classification of different types of labour markets. In particular, it is important to know whether there are rents in some sectors of the labour market: are some kinds of wages systematically "too high"?

In this paper we argue that information on wages and hours of work alone is unlikely to provide a definitive answer to this question. Instead, we suggest that measures of subjective well-being at work, here measured by job satisfaction, can help us to make progress. We thus contribute to the vexed question of how (different) labour markets work.

Existing research has concentrated on the industrial and (to a far lesser extent) occupational distribution of wages. Here we consider labour market sectors that have received somewhat less attention in this respect: self-employment; the public sector; permanent jobs; and full-time jobs. In addition, we contribute to a tradition of comparative work in social science, analysing two countries with very different labour market institutions: France and Great Britain ${ }^{1}$.

Our approach uses both objective (wages) and subjective (job satisfaction) information. Our key argument is that a necessary condition for rents to exist is that job satisfaction should be "inexplicably" higher in one sector than in another. If this higher satisfaction, in a regression framework, is accompanied by higher wages, again in multivariate analysis, then we suggest that such labour markets are typified by wage rents. If a high satisfaction sector is not a high-wage sector, then we expect that other, often non-measured aspects of the job, are producing the higher satisfaction.

Our first conclusion is that unobserved individual heterogeneity is very important, in that the results from cross-section equations suggest a very different characterisation of the labour market than do those from panel regressions. This heterogeneity is key in terms of the current research question, as

\footnotetext{
${ }^{1}$ Examples include trade union density $(\mathrm{GB}=31 \%, \mathrm{Fr}=10 \%)$ and collective bargaining coverage (30+\% vs. 90+\%) in 2000 (OECD, 2004b), the replacement rate (17\% vs 37\%), and the index of employment protection (2.8 vs 1.0) in 2003 (OECD, 2004a).
} 
a matching model of the labour market can easily produce both higher wages and higher utility for one type of worker without there being rents.

Our second conclusion is that there is evidence, in panel regressions, consistent with wage rents in the labour market. In particular, both public sector and permanent jobs (in Great Britain) and fulltime jobs (in France) exhibit job satisfaction and wages that are higher than those in other sectors.

Last, as many might suppose, France and Great Britain are really remarkably different. The wage and job satisfaction characteristics of the four sectors are never the same in the two countries. The public sector is an oft-cited example of how labour markets differ across the Channel. We do indeed find that public sector jobs are not the same, being characterised by wage rents in Great Britain, but higher satisfaction without higher wages in France. This does not necessarily fit in with the popular view of French public sector workers protecting their wage privileges. We also conclude that parttime jobs are a matter of choice to a greater extent in Great Britain than in France.

The paper is organised as follows. Section 2 briefly discusses some results from the existing literature, and Section 3 presents the two datasets. Section 4 contains our main results regarding the presence or absence of rents in France and Great Britain, and Section 5 concludes.

\section{Previous Literature}

Wage determination has been much analysed in labour economics. One key question is whether wages are "too high". In other words, are there rents on the labour market? A labour market rent is defined in Milgrom and Roberts (1992, p.269) as "the portion of earnings in excess of the minimum amount needed to attract a worker to accept a particular job”. If there are wage rents, then some wages could be reduced without changing workers' choices between jobs. The challenge is then to explain why firms would pay higher wages than they need to.

The Economics literature has devoted a great deal of effort to showing that at least part of some wages have a rent-related element. Key contributions include Abowd and Lemieux (1993), Blanchflower, Oswald and Sanfey (1996), and Van Reenen (1996). Although there is now a burgeoning literature on job satisfaction, only little attention has been paid to how such subjective measures might help us to understand the structure of the labour market. The current paper adds to this existing literature by relating wage patterns across sectors to job satisfaction patterns. 
Several recent papers have appealed to both wage and job satisfaction data. Clark (2003) uses BHPS data to conclude that there are occupational wage rents, but no industry wage rents in Great Britain. Lalive (2002) considers wage and job satisfaction data from four waves of the National Longitudinal Study of Youth (NLSY) and concludes that there are (relatively small) rents on the American labour market. Kawaguchi (2003) also uses NLSY data, and compares wages and job satisfaction between employment and self-employment. He finds that the self-employed systematically report higher job satisfaction, despite their lower wages, such that there are nonwage rents. Last, Godechot and Gurgand (2000) use 1997 French data from the Travail et modes de vie survey to show that some classes of private sector workers have both high wages and high job satisfaction, ceteris paribus, whereas public sector workers do not.

There is a also a small literature which has examined job satisfaction (without explicit reference to wages) in the four labour market sectors which we consider: self-employment, public sector, permanent, and full-time. The self-employed are often found to be more satisfied than employees in American and European data (Blanchflower and Oswald, 1998, Blanchflower, Oswald and Stutzer, 2001, and OECD, 2000). Kaiser (2002) finds the self-employed to be less satisfied than the employed in a sample of five countries from the European Community Household Panel (ECHP), although the correlation is again positive in panel data from Great Britain, Germany and Switzerland in Frey and Benz (2003), and in Swiss data in Falter (2004). Self-employment is, however, associated with lower satisfaction in Latin American countries (Graham and Pettinato, 2002).

Permanent jobs are typically found to be more satisfying than temporary jobs (Bardasi and Francesconi, 2004, with BHPS data, and Kaiser, 2002, with ECHP data). Part-time jobs are more satisfying than full time jobs in Great Britain (Bardasi and Francesconi, 2004), but the picture is less clear in other European countries (Kaiser, 2002). Last, both Blanchflower and Oswald (1999) and Kaiser (2002) find that workers in the public sector are more satisfied than their private sector counterparts. Heywood, Siebert and Wei (2002) reproduce this finding in cross-section analysis of the BHPS, but find no correlation in panel regressions. We shall return to this finding below. 


\section{Data}

The empirical work in this paper uses data from the British Household Panel Survey (BHPS) and the French component of the European Community Household Panel (ECHP). In both surveys, all adults in the household are interviewed separately with respect to their socio-demographic characteristics, income, employment, and health. The British Household Panel Survey is an annual panel of roughly 10000 individuals in around 5000 different households in Great Britain. We use data from the first eleven waves (1991-2001). Further details of this survey are available at the following address: http://www.iser.essex.ac.uk/bhps. We use the eight waves of the French component of the ECHP, which was run annually from 1994 to 2001, producing a sample of about 11300 individuals in 2600 households per year. Details of the ECHP are available at http://forum.europa.eu.int/irc/dsis/echpanel/info/data/information.html

One of our key variables is job satisfaction as a proxy measure of utility at work. In the BHPS, all employees are asked about their satisfaction with seven aspects of the job (Promotion Prospects, Total Pay, Relations with Boss, Security, Use of Initiative, Work Itself, and Hours Worked). All of these are measured on a scale of one to seven, where 1 means completely dissatisfied and 7 means completely satisfied. These are followed by the question "All things considered, how satisfied or dissatisfied are you with your present job overall using the same 1-7 scale"? The self-employed are asked about five aspects of the job (the same list as above, less Promotion Prospects and Relations with Boss, which are largely inapplicable here), followed by the same summary question.

In the ECHP, job satisfaction is measured on a six-step ladder, going from not satisfied at all to very satisfied. Job satisfaction is part of a general series of satisfaction questions formulated as follows: "Could you indicate, on a scale going from 1 - "not satisfied at all"- to 6 - "very satisfied"your degree of satisfaction concerning each of the following items: your job or main occupation; your financial situation; your housing; your health; your time available for leisure; your social contacts; and your past education?". In the job part of the questionnaire, another set of questions related to satisfaction with various aspects of the job are asked in a similar way: "Could you indicate, on a scale going from 1 - "not satisfied at all"- to 6 - "very satisfied"- your degree of satisfaction concerning each of the following items: labour income; job security; number of working hours; work schedule; type of activity; working conditions; and commuting distance?". These labour-related questions are asked of all those active in the labour market, independent of 
their status. Table 1 shows the distribution of job satisfaction scores in France and Great Britain.

Table 1. The distribution of job satisfaction

\begin{tabular}{|c|c|c|c|c|c|c|c|c|}
\hline & \multicolumn{4}{|c|}{ Great Britain } & \multicolumn{4}{|c|}{ France } \\
\hline & \multicolumn{2}{|c|}{ With Self-Employed } & \multicolumn{2}{|c|}{$\begin{array}{l}\text { Without Self- } \\
\text { Employed }\end{array}$} & \multicolumn{2}{|c|}{ With Self-Employed } & \multicolumn{2}{|c|}{ Without Self-Employed } \\
\hline & Count & $\%$ & Count & $\%$ & Count & $\%$ & Count & $\%$ \\
\hline 1 & 1113 & 1.8 & 924 & 1.8 & 3887 & 5.1 & 3623 & 5.2 \\
\hline 2 & 1683 & 2.7 & 1420 & 2.8 & 2891 & 3.8 & 2632 & 3.8 \\
\hline 3 & 4072 & 6.5 & 3465 & 6.8 & 6900 & 9.0 & 6343 & 9.1 \\
\hline 4 & 4979 & 8.0 & 4074 & 8.0 & 19897 & 26.0 & 18214 & 26.2 \\
\hline 5 & 13210 & 21.1 & 10887 & 21.5 & 34316 & 44.8 & 31080 & 44.7 \\
\hline 6 & 27399 & 43.8 & 22256 & 43.8 & 8757 & 11.4 & 7.42 & 11.0 \\
\hline 7 & 10076 & 16.1 & 7729 & 15.2 & & & & \\
\hline Total & 62532 & 100 & 50755 & 100 & 76648 & 100 & 69534 & 100 \\
\hline Mean & 5.4 & & 5.4 & & 4.4 & & 4.3 & \\
\hline Median & 6 & & 6 & & 5 & & 5 & \\
\hline Mode & 6 & & 6 & & 5 & & 5 & \\
\hline
\end{tabular}

Source: BHPS 1991-2001; ECHP French component 1994-2001.

We have four key sector variables: self-employment, public sector, permanent, and full-time. In the BHPS, these are defined using the following questions:

1) Are you an employee or self-employed?

2) Which of the types of organisations on this card do you work for (in your main job)? Followed by a show card including private firm, local government, National Health Service, and so on.

3) Thinking about your (main) job, how many hours, excluding overtime and meal breaks, are you expected to work in a normal week?

4) Is your current job a Permanent job, or a Seasonal/Temporary/Contract/Fixed Time job?

In the ECHP, the categories of main professional activity are defined using the following information:

1) The job is full-time on a permanent contract, full-time on a temporary contract, full-time as an independent, part-time (over 15 hours per week) on a permanent contract, part-time on a temporary contract, or part-time as an independent.

2) The respondent is a wage earner employed by the government, employed in a public enterprise, employed in the private sector, or independent. 
3) The usual number of hours worked per week.

Last, we use real gross monthly wages in the BHPS, and real yearly net labour income in the ECHP.

The distribution of these variables in the regression sample is shown in Table 2 below. For the analysis of public/permanent/full-time jobs, we consider employees only. All of the differences in means between sectors are very significant.

Table 2. Satisfaction and labour market status. Descriptive statistics.

\begin{tabular}{|c|c|c|c|c|c|c|}
\hline \multirow[b]{2}{*}{ Sector } & \multicolumn{3}{|c|}{ Great Britain } & \multicolumn{3}{|c|}{ France } \\
\hline & $\%$ & $\begin{array}{c}\text { Job } \\
\text { satisfaction }\end{array}$ & $\begin{array}{c}\text { Labour } \\
\text { Income } \\
\text { (£ per month) }\end{array}$ & $\%$ & $\begin{array}{c}\text { Job } \\
\text { satisfaction }\end{array}$ & $\begin{array}{c}\text { Labour } \\
\text { Income } \\
\text { (FF per year) }\end{array}$ \\
\hline Employee & 90.9 & 5.38 & 1051 & 90.7 & 4.34 & 58067 \\
\hline Self-employed & 9.1 & 5.59 & 1256 & 9.3 & 4.51 & 57529 \\
\hline Private & 68.5 & 5.33 & 1046 & 67.9 & 4.28 & 56106 \\
\hline Public & 27.1 & 5.42 & 1102 & 32.1 & 4.54 & 68616 \\
\hline Other & 4.5 & 5.58 & 992 & $N A$ & & \\
\hline Temporary contract & 6.2 & 5.23 & 737 & 13 & 4.31 & 54755 \\
\hline Permanent contract & 93.8 & 5.38 & 1080 & 87 & 4.43 & 67222 \\
\hline Part-time & 22 & 5.71 & 451 & 17 & 4.31 & 53325 \\
\hline Full-time & 78 & 5.27 & 1230 & 83 & 4.46 & 68181 \\
\hline
\end{tabular}

Source: BHPS 1991-2001; ECHP French component 1994-2001. The PPP between France and the UK ranged from 10.3 in 1994 to 9.5 in 2001

Note that the difference in the absolute level of job satisfaction across countries does not indicate that workers are more satisfied in Great Britain; this simply reflects the different scales of the satisfaction variables. In fact, the average numbers in France (on a one to six scale) are remarkably close to those in Great Britain (on a one to seven scale) minus one.

The bivariate results indicate sharp differences in job satisfaction, the self-employed, public sector workers and those with permanent contracts being more satisfied. These stylised facts characterise both countries. It is noticeable that, in the raw data, part-time workers are more satisfied in Great Britain, but full-time workers are more satisfied in France.

In terms of raw wages, there are differences between the employed and the self-employed (at least in Great Britain), between those on permanent and temporary contracts and between those on parttime versus full-time contracts. Wages are also higher in the public sector than in the private sector. Hence, wages seem to partly follow the same pattern as job satisfaction. If some jobs are both more pleasant and better paid, then the French and the British labour markets are best characterised by 
wage rents rather than compensating differences.

Before reaching this conclusion, however, we must first check that this pattern does not stem from composition effects, i.e. hide the influence of other factors such as age, sex or education, or individuals' preferences. The following section therefore analyses wage and job satisfaction patterns, while controlling for both observed and unobserved heterogeneity.

\section{Main results}

In this section, we move to a multivariate analysis of wages and job satisfaction. Our main aim here is to characterise different sectors of the labour market by their levels of wages and job satisfaction, conditional on other standard demographic and job variables.

The approach is identical across all four of the sectors considered, although (for reasons of space) we only present complete regression results for one of the sectors considered, self-employment, in Table 3. The summary results of interest for public sector, permanent, and full-time workers appear in Table 4.

\section{Wages}

We start with a standard cross-section analysis (more accurately, as we are using panel data, repeated cross-section with correction for clustering of errors at the individual level) of (the $\log$ of) wages between sectors. The full regression results for self-employed vs. employees are reported in column 1 of Table 3, while the estimated coefficients on the public sector, permanent, and full-time variables (entered together) in the sample of employees appear in column 1 of Table 4.

As is very often the case, we find wage differences between sectors that we cannot explain with our right-hand side job and demographic variables. These latter include age and its square, job tenure and its square, number of children, and dummies for male, marital status (there is no separate category for "separated" in the French data), education, occupation and wave. The regressions in Table 3 control for log hours, while those in Table 4, where one of the distinctions is between part and full-time workers, do not.

These cross-section results show that, ceteris paribus, the self-employed earn less than employees; equally public sector, permanent and full-time workers earn more than private sector, temporary 
and part-time workers respectively ${ }^{2}$. An easy conclusion is then that there are wage rents: some jobs pay "too much", and as such the labour market isn't competitive (in the sense that wages could be reduced slightly, without changing workers' choices between jobs). Controlling for hours of work does not change the shape of this wage hierarchy.

This easy conclusion may well be incorrect, for well-known reasons. There could well be unobserved characteristics (such as skill) which differ systematically between sectors. In timehonoured fashion, we then move to panel analysis, here "within" regressions, as the dependent variable is cardinal, to control for any such fixed effects. The results are shown in the second and sixth columns of Tables 3 and 4. With British data, the estimated coefficients change neither sign nor significance, although their size is reduced by around a quarter, suggesting some bias from unobserved individual heterogeneity. The fact that we continue to find systematic differences in wages between sectors might the thought to confirm that there are rents in the labour market. In France, by contrast, although the estimated wage coefficients become insignificant for the public sector and self-employment variables, significant wage differentials persist between full-time jobs and part-time jobs, as well as between permanent and temporary jobs.

The existing literature on labour market structure essentially stops here. However, it is contentious to identify wage differences with labour market structure, competitive or not. The problem, which biases the results, is unobserved job characteristics, such as autonomy or risk. High pay could then just reflect a reward for job disamenities, rather than rents.

It is here that we break relatively new ground by bringing in a second dependent variable. We consider utility from work, as measured by overall job satisfaction, across different labour market sectors. If it is true that wages are "too high", as in the rent interpretation, then high wages should be reflected in high job satisfaction; if wages that are "too high" are compensating for some unpleasant aspects of the job, then we would not expect high wage sectors to be high satisfaction sectors. Similar approaches have recently been used by Clark (2003), Kawaguchi (2003), and Lalive (2002). It is important to note that we do not control for wages in the job satisfaction regressions (see Clark, 2003). Our approach is characterise high wage and high satisfaction sectors

\footnotetext{
${ }^{2}$ The three key sector variables in the second regression - public, permanent, and full-time - are of course not orthogonal. Notably, private sector workers are more likely to be full-time; and full-time workers are more likely to be permanent. However, there is enough independent variation for us to identify the three effects separately.
} 
as having wage rents. Conditioning job satisfaction on wages renders the task of identifying such wage rents impossible.

Table 3. Job Satisfaction and Wages: Self-Employment vs Employment (Full sample).

\begin{tabular}{|c|c|c|c|c|c|c|c|c|}
\hline & \multicolumn{4}{|c|}{ Great Britain } & \multicolumn{4}{|c|}{ France } \\
\hline & \multicolumn{2}{|c|}{ Wages } & \multicolumn{2}{|c|}{ Job Satisfaction } & \multicolumn{2}{|c|}{ Wages } & \multicolumn{2}{|c|}{ Job Satisfaction } \\
\hline & Level & Panel & Level & Panel & Level & Panel & Level & Panel \\
\hline \multirow[t]{2}{*}{ Self-Employed } & $-0.456 * *$ & $-0.326^{* *}$ & $0.231 * *$ & $0.228 * *$ & $-0.129 * *$ & 0.026 & -0.018 & $0.427^{*}$ \\
\hline & $(0.022)$ & $(0.011)$ & $(0.026)$ & $(0.077)$ & $(0.045)$ & $(0.066)$ & $(0.041)$ & $(0.181)$ \\
\hline \multirow[t]{2}{*}{ Number of children } & $-0.009 *$ & -0.003 & $0.048 * *$ & 0.041 & $-0.139 * *$ & $-0.209 * *$ & 0.009 & -0.024 \\
\hline & $(0.005)$ & $(0.004)$ & $(0.008)$ & $(0.026)$ & $(0.009)$ & $(0.010)$ & $(0.008)$ & $(0.027)$ \\
\hline \multirow[t]{2}{*}{ Male } & $0.289 * *$ & & $-0.189 * *$ & & $-0.080 * *$ & & 0.009 & \\
\hline & $(0.009)$ & & $(0.017)$ & & $(0.019)$ & & $(0.022)$ & \\
\hline \multirow[t]{2}{*}{ Married } & 0.019 & $0.082 * *$ & $0.133 * *$ & 0.035 & -0.01 & $0.146^{* *}$ & 0.041 & $0.241 * *$ \\
\hline & $(0.011)$ & $(0.010)$ & $(0.022)$ & $(0.068)$ & $(0.019)$ & $(0.031)$ & $(0.025)$ & $(0.093)$ \\
\hline \multirow[t]{2}{*}{ Separated } & 0.013 & $0.113 * *$ & $0.108 *$ & 0.162 & & & & \\
\hline & $(0.022)$ & $(0.017)$ & $(0.046)$ & $(0.118)$ & & & & \\
\hline \multirow[t]{2}{*}{ Divorced } & -0.011 & $0.099 * *$ & $0.115^{* *}$ & -0.029 & -0.014 & -0.112 & $0.152 *$ & $0.815^{* *}$ \\
\hline & $(0.016)$ & $(0.015)$ & $(0.030)$ & $(0.102)$ & $(0.065)$ & $(0.096)$ & $(0.070)$ & $(0.281)$ \\
\hline \multirow{2}{*}{ Widowed } & 0.036 & $0.075^{*}$ & $0.218 * *$ & 0.041 & -0.006 & 0.068 & -0.001 & 0.224 \\
\hline & $(0.028)$ & $(0.034)$ & $(0.070)$ & $(0.237)$ & $(0.034)$ & $(0.056)$ & $(0.043)$ & $(0.165)$ \\
\hline \multirow[t]{2}{*}{ Age } & $0.064 * *$ & & $-0.052 * *$ & & $0.084 * *$ & & $-0.028 * *$ & \\
\hline & $(0.002)$ & & $(0.005)$ & & $(0.007)$ & & $(0.007)$ & \\
\hline \multirow[t]{2}{*}{ Age-squared/1000 } & $-0.761 * *$ & & $0.697 * *$ & & $-1.064 * *$ & & $0.259 * *$ & \\
\hline & $(0.030)$ & & $(0.058)$ & & $(0.089)$ & & $(0.087)$ & \\
\hline \multirow[t]{2}{*}{ Born Abroad } & 0.022 & & $-0.127^{*}$ & & 0.013 & & $-0.175^{* *}$ & \\
\hline & $(0.022)$ & & $(0.051)$ & & $(0.060)$ & & $(0.057)$ & \\
\hline \multirow[t]{2}{*}{ House Renter } & $-0.134 * *$ & $-0.027 * *$ & $0.045^{* *}$ & $0.138 * *$ & $-0.042 *$ & $-0.051 * *$ & -0.006 & -0.004 \\
\hline & $(0.008)$ & $(0.008)$ & $(0.017)$ & $(0.052)$ & $(0.018)$ & $(0.019)$ & $(0.019)$ & $(0.055)$ \\
\hline \multirow[t]{2}{*}{ Log Hours } & $0.893 * *$ & $0.687 * *$ & $-0.204 * *$ & $-0.299 * *$ & $0.425^{* *}$ & $0.219 * *$ & $0.050 *$ & $0.132 *$ \\
\hline & $(0.012)$ & $(0.007)$ & $(0.018)$ & $(0.047)$ & $(0.029)$ & $(0.020)$ & $(0.023)$ & $(0.055)$ \\
\hline \multirow[t]{2}{*}{ Education: High } & $0.265^{* *}$ & & $-0.219 * *$ & & $0.115^{* *}$ & & 0.03 & \\
\hline & $(0.011)$ & & $(0.023)$ & & $(0.022)$ & & $(0.023)$ & \\
\hline \multirow[t]{2}{*}{ Education: A/O/Nursing } & $0.116^{* *}$ & & $-0.151 * *$ & & $0.357 * *$ & & 0.039 & \\
\hline & $(0.010)$ & & $(0.021)$ & & $(0.025)$ & & $(0.027)$ & \\
\hline \multirow[t]{2}{*}{ Job Tenure } & $0.080 * *$ & & $-0.144 * *$ & & $0.318 * *$ & & 0.014 & \\
\hline & $(0.012)$ & & $(0.028)$ & & $(0.030)$ & & $(0.030)$ & \\
\hline \multirow[t]{2}{*}{ Job Tenure-squared } & -0.001 & & $0.004 * *$ & & $-0.059 * *$ & & 0.013 & \\
\hline & $(0.000)$ & & $(0.001)$ & & $(0.009)$ & & $(0.009)$ & \\
\hline Occupation Dummies & Yes & Yes & Yes & Yes & Yes & Yes & Yes & Yes \\
\hline Wave Dummies & Yes & Yes & Yes & Yes & Yes & Yes & Yes & Yes \\
\hline \multirow[t]{2}{*}{ Constant } & $2.004 * *$ & $4.131 * *$ & & & $8.212 * *$ & $10.654 * *$ & & \\
\hline & $(0.058)$ & $(0.026)$ & & & $(0.168)$ & $(0.088)$ & & \\
\hline Observations & 62622 & 63388 & 62532 & 42086 & 20288 & 23512 & 37206 & 28452 \\
\hline R-Squared & 0.608 & 0.314 & & & 0.225 & 0.069 & & \\
\hline \multicolumn{2}{|c|}{ Number of cross-wave person } & 14203 & & 6514 & & 7949 & & 5072 \\
\hline
\end{tabular}


Table 4. Job Satisfaction and Wages. Employees

\begin{tabular}{lllll|llll}
\hline & \multicolumn{4}{c}{ Great Britain } & \multicolumn{4}{c}{ France } \\
\hline \multirow{4}{*}{ Public Sector } & \multicolumn{3}{c}{ Wages } & \multicolumn{3}{c|}{ Job Satisfaction } & \multicolumn{3}{c}{ Wages } & \multicolumn{3}{c}{ Job Satisfaction } \\
& $0.086^{* *}$ & $0.068^{* *}$ & 0.023 & $0.233^{* *}$ & $0.049^{* *}$ & -0.006 & $0.211^{* *}$ & $0.265^{* *}$ \\
\multirow{3}{*}{ Permanent Contract } & $(0.010)$ & $(0.008)$ & $(0.019)$ & $(0.067)$ & $(0.018)$ & $(0.037)$ & $(0.020)$ & $(0.088)$ \\
& $0.173^{* *}$ & $0.138^{* *}$ & $0.206^{* *}$ & $0.162^{* *}$ & $0.139^{* *}$ & $0.067^{* *}$ & $0.202^{* *}$ & $-0.170^{* *}$ \\
Full-Time & $(0.013)$ & $(0.007)$ & $(0.023)$ & $(0.061)$ & $(0.023)$ & $(0.019)$ & $(0.023)$ & $(0.043)$ \\
& $0.856^{* *}$ & $0.560^{* *}$ & $-0.255^{* *}$ & $-0.242^{* *}$ & $0.352^{* *}$ & $0.197^{* *}$ & $0.236^{* *}$ & $0.345^{* *}$ \\
& $(0.012)$ & $(0.006)$ & $(0.020)$ & $(0.054)$ & $(0.022)$ & $(0.019)$ & $(0.022)$ & $(0.046)$ \\
\hline
\end{tabular}

Source: BHPS 1991-2001; ECHP French component 1994-2001. Robust standard errors in parentheses. * significant at $5 \% ; * *$ significant at $1 \%$. Controls in level regressions: sex, age, job tenure, education, occupation, wave, number of children, marital status, born abroad, and house renter. Controls in panel regressions: occupation, number of children, marital status, wave and house renter. Sample: Employees (except agriculture).

\section{Job Satisfaction}

The results of level and panel estimation of job satisfaction are contained in Tables 3 and 4. Job satisfaction is an ordinal variable. We therefore estimate the cross-section regressions using ordered probit techniques. The panel treatment of ordinal variables is less straightforward. We convert job satisfaction to a dichotomous variable (so as to cut the sample into two roughly equal parts of satisfied versus dissatisfied individuals) and estimate conditional fixed effects logits. As is usual, this model is identified by individuals who move between the different sectors that we examine: roughly speaking, it is the different job satisfaction scores reported by the same individual in different sectors which allows us to estimate the effect of being in the public rather than the private sector, say.

The cross-section results reveal that workers in certain sectors are significantly more satisfied, ceteris paribus, that those in others. In France, this applies to three of the four sectors under consideration (public, permanent, and full-time); In Great Britain this holds for self-employment, permanent and part-time jobs.

These are then "good job" sectors, according to one definition. How many of these would have been identified from wage regressions? The prediction is perfect in France, where all three high satisfaction sectors are also high wage sectors (consistent with wage rents) in cross-section analysis. 
The fit is less good in great Britain, where only permanent jobs exhibit the same wage and satisfaction patterns.

Drawing conclusions about labour market structure from cross-section information is hazardous, for omitted variable reasons. Columns 4 and 8 of Tables 3 and 4 report results from panel job satisfaction regressions. The qualitative relationship changes in three country-sectors (out of eight): from insignificant to positive in the British public sector and French self-employment, and from positive to negative in French permanent jobs.

In British panel data, we find that public sector and permanent workers report both significantly higher levels of satisfaction with their job and higher wages; part-time workers and the selfemployed are significantly more satisfied, even though they earn less. In French panel data, only full-time jobs attract both higher wages and higher satisfaction scores. It is worthwhile noting how many mistakes we would have made by concentrating only on pooled cross-section data. In Great Britain, we would have dismissed the presence of wage rents in the public sector; In France the conclusions regarding fully three out of four sectors change from the cross-section to the panel analysis. Our preferred panel results thus point to the presence of rents, wage or non-wage, in the British and French economies.

How large are these estimated effects? We calculate marginal effects in the panel regressions for a "representative" individual (married with one child, 38 hours per week, Manager/Administrator, house owner, in 1997. These are predicted probabilities from the fixed-effects logit of reporting high satisfaction at time $\mathrm{t}$ (conditional on the replies at all other waves being of low satisfaction see the Stata 8 Manual). The employment-self employment wage gap is $26 \%$ in Great Britain, but zero in France. Changing from a permanent to a temporary job reduces income by around 13\% $(6 \%)$ in Great Britain (France), with corresponding figures of $43 \%$ (18\%) for the full-time to parttime movement. Changing from private-public increases wages by $7 \%$ in Great Britain. All of the panel job satisfaction coefficients are significant. The effect on the estimated probability is over a quarter, except for the permanent to temporary movement, which is around one-sixth. These are arguably large movements.

\section{Heterogeneity}


In a competitive labour market, we would not expect some jobs to be better than others in this sense: those in the less-satisfying jobs should be bidding down wages in the more satisfying jobs until, in equilibrium, all jobs are just as pleasing.

This interpretation of satisfaction differences as rents depends crucially on the hypothesis that workers are identical. However, it is easy to imagine a set-up where individuals have different tastes regarding different job aspects (as in Clark, 2003, and Clark et al.. 2004). Fairlie (2002) provides some evidence of such matching in the case of self-employment. In this case a sorting equilibrium can pertain in which a certain class of workers has both higher wages and higher utility, but there are no rents. An outline is presented below:

Consider two types of workers, A and B. Their utility function is linear:

$$
\mathrm{U}_{\mathrm{i}}=\forall \mathrm{w}-\exists_{\mathrm{i}} \mathrm{D} ; \quad \mathrm{i}=\mathrm{A}, \mathrm{B} .
$$

Assume that B's are less affected by hard work: $\exists_{\mathrm{A}}>\exists_{\mathrm{B}}$. There are two types of job: "easy jobs", subscripted by E, which pay $\mathrm{w}_{\mathrm{E}}$ and involve job disamenities of $\mathrm{D}_{\mathrm{E}}$; and "hard jobs", subscripted by $\mathrm{H}$, which pay $\mathrm{w}_{\mathrm{H}}$ and involve job disamenities of $\mathrm{D}_{\mathrm{H}}$.

A worker of type A will choose an easy job if:

$$
\forall \mathrm{w}_{\mathrm{E}}-\exists_{\mathrm{A}} \mathrm{D}_{\mathrm{E}}>\forall \mathrm{w}_{\mathrm{H}}-\exists_{\mathrm{A}} \mathrm{D}_{\mathrm{H}} \quad \Leftrightarrow=>\quad \mathrm{w}_{\mathrm{H}}<\mathrm{w}_{\mathrm{E}}+\left(\exists_{\mathrm{A}} / \forall\right)\left(\mathrm{D}_{\mathrm{H}}-\mathrm{D}_{\mathrm{E}}\right)
$$

If $\mathrm{w}_{\mathrm{H}}$ is higher than this the A's will prefer the hard job. Similarly, a worker of type B will choose a hard job if

$$
\forall \mathrm{W}_{\mathrm{H}}-\exists_{\mathrm{B}} \mathrm{D}_{\mathrm{H}}>\forall \mathrm{w}_{\mathrm{E}}-\exists_{\mathrm{B}} \mathrm{D}_{\mathrm{E}} \quad \Leftrightarrow \quad=>\mathrm{w}_{\mathrm{H}}>\mathrm{w}_{\mathrm{E}}+\left(\exists_{\mathrm{B}} / \forall\right)\left(\mathrm{D}_{\mathrm{H}}-\mathrm{D}_{\mathrm{E}}\right)
$$

There are thus three possible situations:

(i) $\quad \mathrm{w}_{\mathrm{H}}>\mathrm{w}_{\mathrm{E}}+\left(\exists_{\mathrm{A}} / \forall\right)\left(\mathrm{D}_{\mathrm{H}}-\mathrm{D}_{\mathrm{E}}\right)$ : Both $\mathrm{A}$ and $\mathrm{B}$ prefer the hard job.

(ii) $\quad \mathrm{w}_{\mathrm{E}}+\left(\exists_{\mathrm{B}} / \forall\right)\left(\mathrm{D}_{\mathrm{H}}-\mathrm{D}_{\mathrm{E}}\right)<\mathrm{w}_{\mathrm{H}}<\mathrm{w}_{\mathrm{E}}+\left(\exists_{\mathrm{A}} / \forall\right)\left(\mathrm{D}_{\mathrm{H}}-\mathrm{D}_{\mathrm{E}}\right)$ : There is sorting on the labour market.

(iii) $\mathrm{w}_{\mathrm{H}}<\mathrm{w}_{\mathrm{E}}+\left(\exists_{\mathrm{B}} / \forall\right)\left(\mathrm{D}_{\mathrm{H}}-\mathrm{D}_{\mathrm{E}}\right)$ : Both $\mathrm{A}$ and $\mathrm{B}$ prefer the easy job.

In cases (i) and (iii) it is obvious that B's have higher utility than A's (same wages and 
disamenities, but $\exists_{\mathrm{A}}>\exists_{\mathrm{B}}$, so that the B's suffer less from the job disamenities). What about utilities in the sorting equilibrium? These are given by:

$$
\begin{aligned}
& \mathrm{U}_{\mathrm{A}}^{\text {sort }}=\forall \mathrm{w}_{\mathrm{E}}-\exists_{\mathrm{A}} \mathrm{D}_{\mathrm{E}} \\
& \mathrm{U}_{\mathrm{B}}^{\text {sort }}=\forall \mathrm{W}_{\mathrm{H}}-\exists_{\mathrm{B}} \mathrm{D}_{\mathrm{H}} \\
& \text { Hence } \mathrm{U}_{\mathrm{B}}{ }^{\text {sort }}>\mathrm{U}_{\mathrm{A}}{ }^{\text {sort }} \text { if }
\end{aligned}
$$

$$
\mathrm{w}_{\mathrm{H}}>\mathrm{w}_{\mathrm{E}}+(1 / \forall)\left(\exists_{\mathrm{B}} \mathrm{D}_{\mathrm{H}}-\exists_{\mathrm{A}} \mathrm{D}_{\mathrm{E}}\right)
$$

However, the sorting condition in (ii) requires that:

$$
\mathrm{w}_{\mathrm{H}}>\mathrm{w}_{\mathrm{E}}+\left(\exists_{\mathrm{B}} / \forall\right)\left(\mathrm{D}_{\mathrm{H}}-\mathrm{D}_{\mathrm{E}}\right)
$$

And the right-hand side of (4) is larger than the right-hand side of (3), as $\exists_{\mathrm{A}}>\exists_{\mathrm{B}}$.

Hence, whenever there is sorting, the B's (in the "hard jobs") have both higher wages and higher utility. However, these are not rents, in the sense that the A's still prefer the easy jobs to the hard jobs in the sorting equilibrium.

Can we ever prove that such sorting equilibria exist? Again, it is difficult, as the parameters of interest, the D's and $\exists$ 's, are unobservable. Certainly, a level job satisfaction regression can't prove anything unambiguously, but panel regressions can help.

How can we interpret panel job satisfaction regression results in the above context? The regressions are identified by individuals who move from hard to easy jobs, or from easy jobs to hard jobs. If the allocation of individuals to jobs were without error, then we would not see any such movement. One interpretation is then that there are initial misclassification or mistakes (people don't always know which type they are). Hence, individuals who find out that they are hard workers, but have easy jobs, will move to hard jobs. We will then observe the following as a result of this movement:

$>$ Wages rise, and utility rises. This implies a positive correlation in panel regressions, as we see above in the English case.

However, mobility can occur in the other direction as well: individuals who discover that they are not hard workers, but have hard jobs, will move to easy jobs. In this case we observe: 
Wages fall, and utility rises. This implies a negative correlation in panel regressions, as we observe for permanent contract jobs in the French labour market.

The moral is that a sorting model implies that wages and utility are positively correlated in crosssections; however in panel data (i.e. identified by movers) there will only be a positive correlation if there are initially more mistakes by hard workers. As there is no a priori reason why this should be the case, we argue that a positive sector coefficient in both panel wage and panel satisfaction equations reflects rents.

\section{Discussion}

The text table below summarises the results in Tables 3 and 4 above. High-wage, high-satisfaction jobs, ceteris paribus, are permanent and public sector in Great Britain, and full-time in France. These jobs are both more satisfactory and better paid, controlling for unobserved individual heterogeneity. In this light, there is evidence of wage rents in both labour markets. The British result contrasts with that of Heywood, Siebert and Wei (2002), who find no significant satisfaction differential in the public sector. However, their satisfaction equations condition on wages. As such, the two sets of results are consistent. British public sector workers earn wage rents; however, holding wages constant, they may be no more satisfied than private sector workers (in other words, their higher job satisfaction seems to come from their higher wages).

Job Satisfaction and Wages: Summary

\begin{tabular}{|c|c|c|c|c|c|c|c|c|}
\hline & \multicolumn{4}{|c|}{ Great Britain } & \multicolumn{4}{|c|}{ France } \\
\hline & \multicolumn{2}{|c|}{ Level } & \multicolumn{2}{|c|}{ Panel } & \multicolumn{2}{|c|}{ Level } & \multicolumn{2}{|c|}{ Panel } \\
\hline & Wages & $\begin{array}{c}\text { Job } \\
\text { Satisfaction }\end{array}$ & Wages & $\begin{array}{c}\text { Job } \\
\text { Satisfaction }\end{array}$ & Wages & $\begin{array}{c}\text { Job } \\
\text { Satisfaction }\end{array}$ & Wages & $\begin{array}{c}\text { Job } \\
\text { Satisfaction }\end{array}$ \\
\hline Self-Employment & - & + & - & + & - & 0 & 0 & + \\
\hline Public Sector & + & 0 & + & + & + & + & 0 & + \\
\hline Permanent Contract & + & + & + & + & + & + & 0 & - \\
\hline Full-Time & + & - & + & - & + & + & + & + \\
\hline
\end{tabular}

On the contrary, self-employment and part-time jobs are more satisfactory in Great Britain, but are not associated with higher wages; in France, being self-employed and in the public sector is more satisfactory but not more lucrative. This could reflect rents resulting from some, non-wage, aspect of the job. 
The fact that the self-employment sector seems to structured in the same way in both France and Great Britain is something of a surprise. Our prior was that risk-taking would be less rewarded in France, with public sector rents acting as a magnet for skilled workers. This prior is consistent with evidence showing that entrepreneurs are less numerous in France than in other countries, in particular the UK (Blanchflower, 2000). In fact, our results suggest that the self-employment rent is similar in nature in both countries, with more satisfying work, but not higher pay. It is worth noting that Kawaguchi (2003) also concludes that self-employment is characterised by non-wage rents in the USA.

Another striking cross-country difference is in the appreciation of full-time versus part-time jobs. Full-time jobs are less satisfying in Great Britain, despite their higher wages, suggesting an appreciation of flexibility in work time. However, the most salient feature of the French labour market is the higher value of full-time jobs in terms of both pay and job satisfaction. As Table 6 (below) shows, full-time jobs are also associated with more pleasant job content. As such, hours flexibility seems to be appreciated in Great Britain, but viewed negatively in France, where low hours and "bad jobs" go hand in hand. This part-time result is not, incidentally, due to a correlation between part-time and private sector jobs: the rate of part-timers in the public sector (19\%) is similar to that in the private sector $(17 \%)$. De facto, nearly half of French part-timers state that they would prefer to work more hours. The corresponding figure in the BHPS is under twenty per cent. This disparity in hours preferences is confirmed by our regression coefficients in Table 4: part-time work seems to be a result of choice in Great Britain, whereas it is more of a necessary evil in France.

It is of some interest to ask for whom these results hold: separate regressions were then run for men and women (Table 5). The results are remarkably similar to those found over the whole sample. In Great Britain, the higher satisfaction from self-employment is only found for men (around threequarters of the self-employed are men). In addition, the higher job satisfaction associated with permanent work is found only for women. Higher public sector job satisfaction is found for both sexes (although of borderline significance for men). In France the estimated coefficient on the public sector and self-employment variables in panel job satisfaction regressions are only significant for women. 
Table 5. Job Satisfaction and Wages. Men and Women

\begin{tabular}{|c|c|c|c|c|c|c|c|c|}
\hline \multirow{3}{*}{ Great Britain } & \multicolumn{4}{|c|}{ Women } & \multicolumn{4}{|c|}{ Men } \\
\hline & \multicolumn{2}{|c|}{ Wages } & \multicolumn{2}{|c|}{ Job Satisfaction } & \multicolumn{2}{|c|}{ Wages } & \multicolumn{2}{|c|}{ Job Satisfaction } \\
\hline & Level & Panel & Level & Panel & Level & Panel & Level & Panel \\
\hline \multicolumn{9}{|l|}{ Regression 1 : } \\
\hline Self-employed & $\begin{array}{l}-0.420^{* *} \\
(0.045)\end{array}$ & $\begin{array}{l}-0.214^{* *} \\
(0.019)\end{array}$ & $\begin{array}{l}0.146^{* *} \\
(0.049)\end{array}$ & $\begin{array}{l}0.162 \\
(0.144)\end{array}$ & $\begin{array}{l}-0.427 * * \\
(0.024)\end{array}$ & $\begin{array}{l}-0.343^{* *} \\
(0.014)\end{array}$ & $\begin{array}{l}0.235^{* *} \\
(0.032)\end{array}$ & $\begin{array}{l}0.258^{* *} \\
(0.092)\end{array}$ \\
\hline \multicolumn{9}{|l|}{ Regression 2: } \\
\hline Public & $\begin{array}{l}0.122 * * \\
(0.013)\end{array}$ & $\begin{array}{l}0.072^{* *} \\
(0.011)\end{array}$ & $\begin{array}{l}0.021 \\
(0.025)\end{array}$ & $\begin{array}{l}0.240^{* *} \\
(0.086)\end{array}$ & $\begin{array}{l}0.006 \\
(0.013)\end{array}$ & $\begin{array}{l}0.056^{* *} \\
(0.012)\end{array}$ & $\begin{array}{l}0.045 \\
(0.031)\end{array}$ & $\begin{array}{l}0.209 \\
(0.108)\end{array}$ \\
\hline Permanent Contract & $\begin{array}{l}0.196^{* *} \\
(0.017)\end{array}$ & $\begin{array}{l}0.149^{* *} \\
(0.010)\end{array}$ & $\begin{array}{l}0.203 * * \\
(0.031)\end{array}$ & $\begin{array}{l}0.228 * * \\
(0.080)\end{array}$ & $\begin{array}{l}0.162^{* *} \\
(0.019)\end{array}$ & $\begin{array}{l}0.126^{* *} \\
(0.010)\end{array}$ & $\begin{array}{l}0.185^{* *} \\
(0.036)\end{array}$ & $\begin{array}{l}0.057 \\
(0.096)\end{array}$ \\
\hline Full-Time & $\begin{array}{l}0.800^{* *} \\
(0.013)\end{array}$ & $\begin{array}{l}0.555^{* *} \\
(0.008)\end{array}$ & $\begin{array}{l}-0.210^{* *} \\
(0.024)\end{array}$ & $\begin{array}{l}-0.237 * * \\
(0.063)\end{array}$ & $\begin{array}{l}0.658^{* *} \\
(0.032)\end{array}$ & $\begin{array}{l}0.458^{* *} \\
(0.012)\end{array}$ & $\begin{array}{l}-0.173^{* *} \\
(0.047)\end{array}$ & $\begin{array}{l}-0.200 \\
(0.116)\end{array}$ \\
\hline \multirow[t]{2}{*}{ France } & \multicolumn{2}{|c|}{ Wages } & \multicolumn{2}{|c|}{ Job Satisfaction } & \multicolumn{2}{|c|}{ Wages } & \multicolumn{2}{|c|}{ Job Satisfaction } \\
\hline & Level & Panel & Level & Panel & Level & Panel & Level & Panel \\
\hline \multicolumn{9}{|l|}{ Regression 1 : } \\
\hline Self-employed & $(0.072)$ & $(0.102)$ & $(0.063)$ & $(0.315)$ & $(0.057)$ & $(0.089)$ & $(0.053)$ & $(0.229)$ \\
\hline \multicolumn{9}{|l|}{ Regression 2: } \\
\hline Public & $\begin{array}{l}0.027 \\
(0.023)\end{array}$ & $\begin{array}{l}-0.056 \\
(0.048)\end{array}$ & $\begin{array}{l}0.172 * * \\
(0.028)\end{array}$ & $\begin{array}{l}0.293 * \\
(0.116)\end{array}$ & $\begin{array}{l}0.046 \\
(0.029)\end{array}$ & $\begin{array}{l}0.067 \\
(0.058)\end{array}$ & $\begin{array}{l}0.261^{* *} \\
(0.030)\end{array}$ & $\begin{array}{l}0.219 \\
(0.137)\end{array}$ \\
\hline \multirow[t]{2}{*}{ Permanent Contract } & $0.126^{* *}$ & $0.055^{*}$ & $0.182 * *$ & $-0.204 * *$ & $0.153 * *$ & $0.083^{* *}$ & $0.147 * *$ & $-0.148^{*}$ \\
\hline & $(0.032)$ & $(0.025)$ & $(0.032)$ & $(0.056)$ & $(0.035)$ & $(0.029)$ & $(0.035)$ & $(0.067)$ \\
\hline \multirow[t]{2}{*}{ Full-Time } & $0.352^{* *}$ & $0.203^{* *}$ & $0.156^{* *}$ & $0.254^{* *}$ & $0.344^{* *}$ & $0.190^{* *}$ & $0.480^{* *}$ & $0.476^{* *}$ \\
\hline & $(0.025)$ & $(0.024)$ & $(0.025)$ & $(0.059)$ & $(0.043)$ & $(0.031)$ & $(0.041)$ & $(0.073)$ \\
\hline
\end{tabular}

Source: BHPS 1991-2001; ECHP French component 1994-2001. Robust standard errors in parentheses. * significant at $5 \%$;* significant at $1 \%$. Controls in level regressions: age, education, occupation, wave, number of children, marital status, born abroad, and house renter. Controls in panel regressions: occupation, number of children, marital status, wave and house renter. Regression 1 = Workers; Regression 2 = Employees. Agriculture excluded.

We can also examine domain job satisfaction scores in terms of our different sectors (Table 6). In France, a variance decomposition of job satisfaction reveals that the most important domain appears to be the type of work, followed by pay, job security, hours of work and commuting time. Clark (2001) uses quit data to establish a similar ranking in Great Britain. How are domain job satisfaction scores distributed across the various sectors of the labour market? The results are in a sense unsurprising. In Great Britain, the higher job satisfaction of the self-employed is concentrated in pay, the work itself and initiative, but not in job security. The higher job satisfaction of permanent workers is concentrated in their promotion prospects, job security and use of initiative, 
but not in relations with their boss.

In France, the sources of satisfaction also differ by sector, and match up, to a certain extent, with those in Great Britain. Of interest is the sharp negative effect of self-employment on hours satisfaction in France, compared to no effect in Great Britain. It is especially noteworthy that in both countries, public sector workers report (weakly) higher job satisfaction than their private sector counterparts with respect to all of the domain measures.

The two countries differ with respect to permanent jobs ("good" jobs in Great Britain, but "bad" jobs in France). In terms of the domain satisfactions that we can directly compare between the two countries, permanent jobs are particularly dissatisfying with respect to their pay in France. A similar disagreement results for full-time jobs (satisfying in France, dissatisfying in Great Britain). This feeds through to domain satisfaction. In Great Britain, full-time jobs are less satisfying than part-time jobs with respect to all four of the domains that we can compare between countries. However, in France, full-time jobs are more satisfying with respect to pay and the work itself.

The domain satisfaction scores can also inform about non-wage rents. The public sector in France is characterised by high satisfaction but no wage differential, whereas we posited wage rents in Great Britain. The domain results show that public sector jobs largely outperform private sector jobs in the domain satisfaction scores. In particular, public sector scores are higher for security, activity and hours satisfaction in both France and Great Britain. The public sector scores no higher in France for pay satisfaction (with a t-statistic of essentially zero), whereas in Great Britain, the coefficient is positive and borderline significant at the five per cent level. 


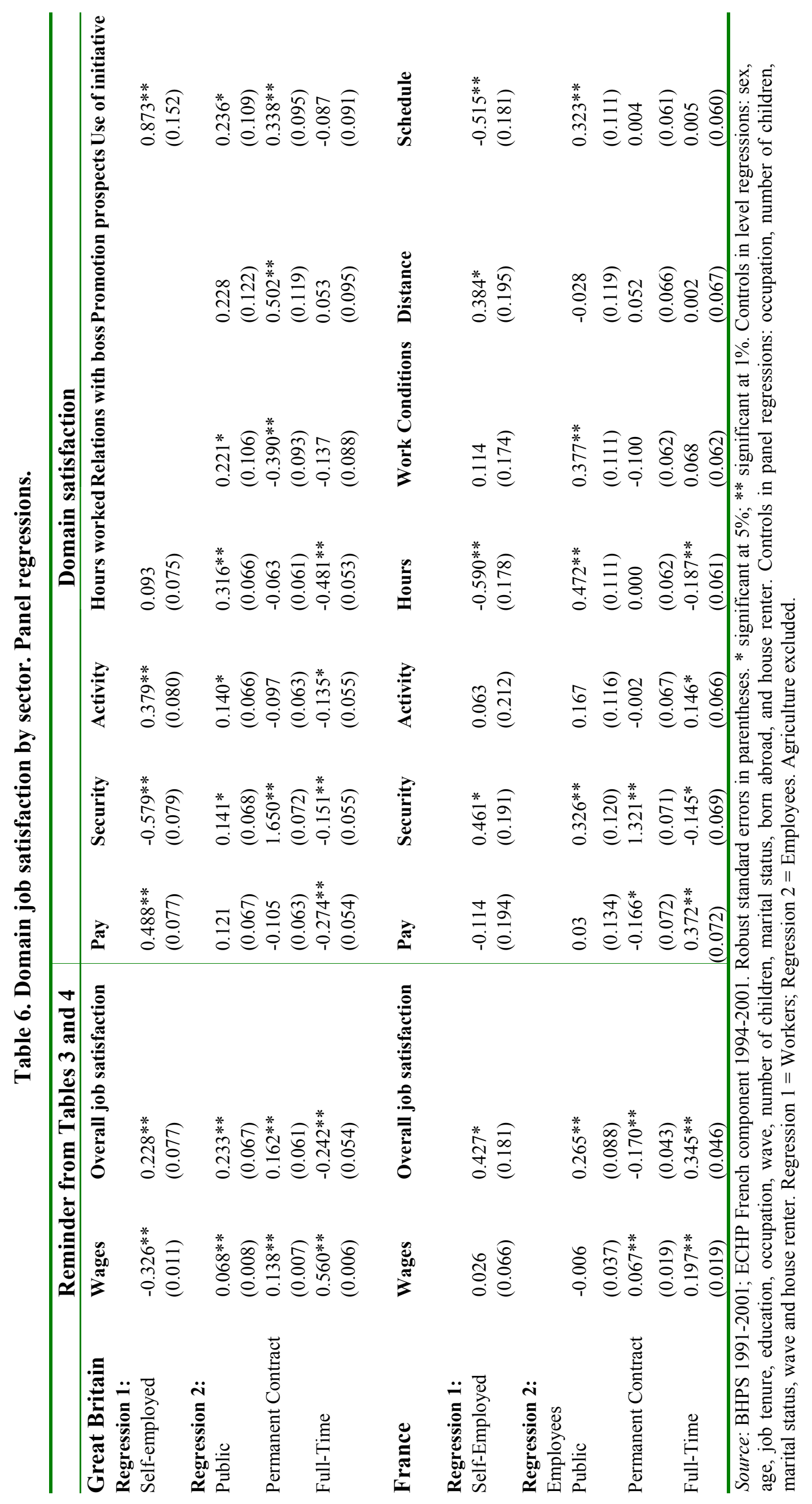




\section{Conclusion}

This paper considered the structure of the French and British labour markets. Using both objective wage and subjective satisfaction data, it has shown that in some sectors workers enjoy both higher wages and higher job satisfaction. One interpretation is that this indicates the presence of wage rents on the labour market. These rents are found in British public sector and permanent contracts; in France, wage rents are concentrated in full-time as opposed to part-time jobs. Hence, the data do not necessarily support the usual a priori that the French labour market is structured along an insider-outsider model whereby wage rents are captured by public-sector insiders to the detriment of the private sector.

However, this is precisely the picture that would have been painted by the analysis of only crosssection regressions. These indicate that public sector workers are both more satisfied and better paid in France, but not in Great Britain. This result is then inverted in our (preferred) panel results, demonstrating the importance of unobserved individual heterogeneity (and hence of panel techniques). The higher cross-section wages of public sector workers in France seem to result from an unobserved fixed effect, rather than rents. Similarly, in Great Britain, "naturally" happy workers tend to gravitate towards private sector, rather than public sector, jobs.

In terms of labour market rents, we can conclude, perhaps unexpectedly, that these seem to be at least as pervasive in Great Britain as in France. In addition, permanent and full-time jobs really do not seem to be equivalent across the two countries. Our most general conclusion is that crosssection analysis can provide misleading results as to the nature of labour markets, and that subjective data provides a useful complement to the standard analysis of wages. To this extent, we expect to see them become a standard part of the economist's toolkit. 


\section{References}

Abowd, J., \& Lemieux, T. (1993). "The Effects of Product Market Competition on Collective Bargaining Agreements: The Case of Foreign Competition in Canada". Quarterly Journal of Economics, 108, 983-1014.

Bardasi, E., \& Francesconi, M. (2004). "The impact of atypical employment on individual wellbeing: evidence from a panel of British workers". Social Science and Medicine, 58, 16711688.

Blanchflower, D,G. (2000). "Self-employment in OECD countries". Labour Economics, 7, 471-505.

Blanchflower, D.G,. \& Oswald, A.J. (1998). "What Makes an Entrepreneur?". Journal of Labor Economics, 16, 26-60.

Blanchflower, D.G., \& Oswald, A.J. (1999). "Well-Being, Insecurity and the Decline of American Job Satisfaction". Dartmouth College, mimeo.

Blanchflower, D.G., Oswald, A.J., \& Sanfey, P. (1996). "Wages, Profits and Rent-Sharing". Quarterly Journal of Economics, 111, 227-252.

Blanchflower, D.G., Oswald, A.J., \& Stutzer, A. (2001). "Latent Entrepreneurship Across Nations". European Economic Review, 45, 680-691.

Clark, A.E. (1997). "Job Satisfaction and Gender: Why are Women so Happy at Work?". Labour Economics, 4, 341-372.

Clark A.E. (2001). "What really matters in a job? Hedonic measurement using quit data". Labour Economics, 8, 223-242.

Clark, A.E. (2003). "Looking for Rents Using Subjective Labour Market Data". DELTA, mimeo.

Clark, A.E., Etilé, F., Postel-Vinay, F., Senik, C., \& van der Straeten, K. (2004). "Heterogeneity in Reported Well-Being: Evidence from Twelve European Countries". Economic Journal, Forthcoming.

Fairlie, R. (2002). "Drug Dealing and Legitimate Self-Employment". Journal of Labor Economics, 20, 538-567.

Falter, J.-M. (2004). Are the Self-Employed Happier at Work?, University of Geneva, mimeo. 
Frey, B.S., \& Benz, M. (2003). "Being Independent is a Great Thing: Subjective Evaluations of Self-Employment and Hierarchy". University of Zurich, IEW Working Paper No.135.

Godechot, O., \& Gurgand, M. (2000). "Quand les salariés jugent leur salaire". Economie et Statistique, 331, 3-24.

Graham, C. and Pettinato, S. (2002). Happiness and Hardship. Opportunity and Insecurity in New Market Economies. Washington D.C., Brookings Institution Press.

Heywood, J., Siebert, W., \& Wei, X. (2002). "Worker Sorting and Job Satisfaction: The Case of Union and Government Jobs". Industrial \& Labor Relations Review, 55, 595-609.

Kaiser, L. (2002): 'Job Satisfaction: A Comparison of Standard, Non-Standard, and SelfEmployment Patterns across Europe with a Special Note to the Gender/Job Satisfaction Paradox’ EPAG Working Paper 27, Colchester: University of Essex.

Kawaguchi, D. (2003). "Compensating Wage Differentials among Self-Employed Workers: Evidence from Job Satisfaction Scores". University of Tsukuba, mimeo.

Lalive, R. (2002). "Do Wages Compensate for Workplace Amenities?". University of Zurich, mimeo.

Milgrom, P., \& Roberts, J. (1992). Economics, Organization and Management. New Jersey: Prentice Hall.

OECD. (2000). "The Partial Renaissance of Self-Employment". OECD Employment Outlook.

OECD. (2004a). "Employment protection regulation and labour market performance". OECD Employment Outlook.

OECD. (2004b). "Wage-setting institutions and outcomes". OECD Employment Outlook.

Van Reenen, J. (1996). "The Creation and Capture of Rents: Wages and Innovation in a Panel of U.K. Companies". Quarterly Journal of Economics, 111, 195-226. 